\title{
RETRACTED ARTICLE: Property market price response to flood-hazard
}

\author{
Muhammad Najib Razali ${ }^{1}$ (D) . Siti Hafsah Zulkarnain ${ }^{2,3} \cdot$ Zakri Tarmidi $^{1}$. \\ Nurul Hana Adi Maimun ${ }^{1}$. Yasmin Mohd. Adnan ${ }^{4}$. Muhamad Ali Yuzir²
}

Received: 13 September 2018 / Accepted: 21 September 2018 / Published online: 27 September 2018 (c) Springer Nature B.V. 2020

The Editor-in-Chief has retracted this article [1] because it was published in error before the peer review process was completed. None of the authors responded to correspondence about this retraction. The online version of this article contains the full text of the retracted article as electronic supplementary material.

\section{Reference}

1. Razali MN, Zulkarnain SH, Tarmidi Z, Adi Maimun NH, Mohd. Adnan Y, Yuzir MA (2018) Property market price response to flood-hazard. Nat Hazards. https://doi.org/10.1007/s1 1069-018-3495-5

Electronic supplementary material The online version of this article (https://doi.org/10.1007/s1106 9-018-3495-5) contains supplementary material, which is available to authorized users.

Muhammad Najib Razali

mnajibmr@utm.my

1 Faculty of Built Environment and Surveying, Universiti Teknologi Malaysia, Johor Bahru, Johor, Malaysia

2 Malaysia-Japan International Institute of Technology (MJIIT), Universiti Teknologi Malaysia, Kuala Lumpur, Malaysia

3 Faculty of Architecture, Planning and Surveying, Universiti Teknologi MARA, Shah Alam, Selangor, Malaysia

4 Faculty of Built Environment, Universiti Malaya, Kuala Lumpur, Malaysia 